\title{
MAHALLA INSTITUTE - THE FOUNDATION OF CIVIL SOCIETY OF UZBEKISTAN
}

\author{
Rahimov Ilhomjon Azimjonovich ${ }^{1}$ \\ $\mathrm{PhD}$ applicant, \\ Teacher of Fergana polytechnic institute, \\ Uzbekistan $^{1}$
}

\author{
Ergashev Umidjon Obidjonovich ${ }^{2}$ \\ $\mathrm{PhD}$ applicant, \\ Senior teacher of Fergana polytechnic institute, \\ Uzbekistan $^{2}$
}

Article DOI: https://doi.org/10.36713/epra3567

\begin{abstract}
ANNOTATION
The article tells about the important social institutions of the Uzbek people for thousands of years - the historical stages of development of the mahalla, the state of the Soviet period, and the modern features of securing independence and democratic development.
\end{abstract}

KEY WORDS: reform, social life, social institution, governance, neighborhood, self-government, neighborhood institution, democratic development, civil society, elections.

\section{INTRODUCTION}

In the democratic society being built in Uzbekistan, the neighbourhood, that is, the national model of civil self-governance, is recognized directly as an institution of democracy. Its legal basis is clearly defined in Article 105 of the Constitution of the Republic of Uzbekistan: "In the towns, villages and streets, as well as in its neighborhoods, citizens' assemblies are self-governing bodies, electing a chairman (aksakal) and his advisers for a period of two and a half years".[1].

The interest in scientific study of this issue has only increased after the establishment of a new, fair democratic society in a number of developed countries, including the Republic of Uzbekistan.

Some theoretical and practical problems related to this topic are from Uzbek legal scholars Sh.I.Jalilov [2], A.Saidov [3], K.Komilov [4], M. Suvonkulov [5], S.Sultonov [6], A.Toolaganov [7], G.Malikova [8], G.Ismailova [9], Z.Reymova [10], historians G.Umarova [11], R.R. Shamsutdinov and A.Ishakov [12].

\section{MATERIALS AND METHODS}

The methods of comparative-critical study, analysis, historical and logical analysis of problematic historical, political, philosophical, sociological, psychological, and pedagogical literature were used in the study.

\section{OBJECTIVES}

Neighborhood is a unique form of social life of people in Uzbekistan, formed over centuries. History shows that there have been neighborhoodss in our country since ancient times, The Muzrabad district of Surkhandarya region crosses the Sherabad Desert, an archaeological monument in the area near the river Ulanbulaksay, Academician Ahmadali Askarov, who conducted archaeological research in Sopollitepa in 1969-74, says that the area of Sopollitepa is about 3 hectares, and its central part is about 1 hectare. The residential complexes in the fortress are located along its inner walls; They are divided into 8 neighborhoods along the streets. [13].

Literature shows that neighborhoods have a millennium history. For example, Narshakhi in his book "History of Bukhara" returns to the fact that there were several mahallas in Bukhara 1100 years ago. In his work "Hayrat ul-abror", Alisher Navoi describes the neighborhood as "a suburban town", noting that the city of Herat is made up of "one hundred towns", that is, neighborhoods. The example of the neighborhood where Navoi lived shows how high the human qualities such as brotherhood, kindness, mentorship and discipleship are. The great thinker Alisher Navoi left warm memories and clear ideas about the neighborhoods. In his Majolisunnafois book, Alisher Navoi writes about the neighborhoods.

"Dost Mohammad is from the Margoni neighborhood. It is good for poetry and problems". A. 
Navoi writes that there is respect, equality among neighborhoodss, and that horns and gadgets are well cared for. Historically, A. Navoi also lived in this neighborhood. It says about the location of the yard in which Navoi is located: "It was on the western border with the southern border of this enclosed courtyard."

In short, the great ones were kind to the neighborhood and people they lived in. Navoi has been living in Herghan's Morgan neighborhood and has made it the most beautiful place in the city. Many of his great works were also born in this neighborhood [14].

We see that during the period when Turkestan was colonized by the Russian Empire, the rule of the country was based on violence and kept as a permanent method. The Russian government has always emphasized that the Turkestan peoples "will not be subject to their will and consent" and that the country should be completely free. On this basis, Turkiston established a system of governorship of the general. The head of the district in the system of urban and rural management is the precinct officer, who is subordinated to the elders of the makhally, fifty leaders and ten leaders. Thus, the governorgeneral of Turkestan kept control of his military and civilian power in his hands. The system of local government was in the hands of the Russian authorities. The Russian administration's "selfgovernment and suffrage" is a form of brutality, which in its hands is in control of the case.[15].

An example of Tashkent is the ancient local system of local government. Generally, mahalla residents were more likely to be engaged in crafts, trade or agricultural activities, depending on the nature and nature of the area in which they live. Large neighborhoods with rich historical traditions include Oktepa, Okmachit, Balandmachit, Devonbegi, Kukcha, Almazar, Isfara Guzar, Altintepa, Agaabad, Samarkand Gate, Kamolon, Deep Bridge, Okchi, Uzbek and other mahallas [16].

At the beginning of the 20th century, the mahallas were ruled by the centurion (elders) elected by the chiefs of the ministers - the commanders. The centurion and his assistants supervised all public affairs and ceremonies in the neighborhood, as well as representing the interests of the community in city councils and city offices.

\section{METHODOLOGY}

The main objectives of the makhallas are to hold rituals, to organize and beautify their territory, to educate the younger generation in a spirit of public order, to maintain order in society, to control the observance of all traditional norms, to adhere to customs and punish those who violate community obligations. Neighborhood authorities have organized public works related to the cleaning of the ditches, the construction of streets and the improvement of the neighborhood. All this was done together by hashar.

The Soviet government regarded the neighborhood as a ruse in the past. From this he proceeded to establish a policy of building a "progressive" industrial society here by abolishing traditional national rule. Since the early 20 s, the Soviet government has sought to limit and subjugate the functions of the makhallya, which has had an impact on the activities of the neighborhood. However, the mall has demonstrated its survival and has withstood any attacks on the traditional way of life and communication and attempts to eliminate them. He preserved old customs and rituals.

In the 20-30s, the neighborhood was involved in an "attack" on old life - in attempting to release paranoids and liberate women. At the same time, the eradication of illiteracy in the neighborhood has played an important role in educating the masses, improving the places (building roads, teahouses, schools).

On April 17, 1932, for the first time in Uzbekistan, a Charter of the Urban Committee was issued. In 1935-36, neighborhood committees were established under the chairmanship of an elder in the neighborhood to oversee all public affairs.

The Soviet government, which opposed many traditional Uzbek structures, had to retreat from the struggle with the neighborhood. This power did not go to the mall. In 1932 the "Provision on neighborhood committees in the cities of Uzbekistan" was issued. In 1938 the assault on the neighborhood was stopped altogether. It was decided that they should exist alongside new socialist structures and complement these structures [17].

In August 1961, the Regulation "On mahalla committees in the cities, villages, villages and villages of the Republic" issued by the Supreme Soviet of the Republic of Uzbekistan was not granted the status of a legal entity. "Neighborhood committees could not engage in any financial activity". The rights and powers of the neighborhood were limited.

After Uzbekistan gained independence, the attitude towards neighborhood changed dramatically. In accordance with Article 105 of the Constitution of the Republic of Uzbekistan and the Law on Citizens' Self-Government Bodies adopted in the Senate in 1993, neighborhoods have legal status and are part of the local government. The neighborhoodss, as the legal backbone of the state, have their own property, financial budget, and book-keeping account. According to this law, each neighborhood can create its own charter, open small businesses, sell its own products, distribute part of it free to the needs of the neighborhood, provide employment and cultural services to its residents. 
According to the Decree of the President of the Republic of Uzbekistan dated October 10, 2013 No PQ-2050 "On the organization of training courses for training of civil self-government employees", the organization of professional and managerial skills, legal and socio-economic knowledge, their non-profit organizations, as well as the Council of Ministers of the Republic of Karakalpakstan, with the aim of facilitating the improvement of its activities aimed at the formation and development of mechanisms of social partnership with public authorities and administration;

The regional and Tashkent city governments organized training courses for civil servants in the form of public educational institutions. All the abovementioned legal acts are, first of all, the legal basis for the implementation of the principle "From a strong state to a strong civil society". After all, in our country, the institution of citizens' self-government as one of the most important parts of civil society is an important factor in the immediate development of the institution of makhallya, which is unique to us. Consequently, the development of the mahalla institution on the basis of the Citizens' SelfGovernment Institute, its transformation into the center of family business and the transfer of a number of other functions to the community are characterized by the following features:

First, increasing the role of the neighborhood on the basis of the Institute of Civil Self-Government fully corresponds with the national mentality and centuries-old traditions and management traditions of our people;

Secondly, the institution of neighborhood unmatched in any other country in the world is emerging as the most important part of civil society institutions in the country and plays a leading role in its development;

Thirdly, the introduction of community structures in the neighborhood should ensure that peace and tranquility in the country should begin directly with neighborhood, with each family living there;

\section{RESULTS}

Today, gatherings of citizens, which are functioning independently, are an important institution in the formation of civil society as selfgoverning bodies. On February 3, 2017, President of the Republic of Uzbekistan Shavkat Mirziyoev signed a decree "On measures to further improve the institution of neighborhood". This decree marks a new stage in the further development of the mahalla institute [18]. It is also planned to increase staff and strengthen material and technical base of "Nuroniy" and "Mahalla" foundations by the President; additional measures will be taken to further enhance their role and place in the life of our society".[19].

\section{CONCLUSION}

In conclusion first of all, it is related to the study and objective assessment of the reform process in the field of self-government in Uzbekistan;

Secondly, the extensive study, research and further intensification of the work done in this area on the historical roots, development, role and role of the bodies of self-governance in the country;

Third, it is known from history that the works and ideas of thinkers who lived during the medieval Renaissance in the East were related to the study of their ideas about fair civil society;

Fourth, to increase the legal culture of citizens in the process of building civil society and to increase their activity in self-government bodies;

Fifth, it is determined by the need to develop conclusions, proposals and recommendations aimed at further deepening of the role and role of selfgovernance bodies in the formation of civil society.

\section{REFERENCES}

1. The Constitution of the Republic of Uzbekistan. -Tashkent: "Uzbekistan", 2018. - B. 29.

2. Jalilov Sh. Local Government Reform: Experience and Challenges. -T., 1994. 192 b .; Jalilov Sh. The neighborhood is in the process of renovation. - T., 1994. $72 b$.; Jalilov Sh. Neighbourhood: Legal Guarantee for Self-Government. - T., 1999. 320 b .; Jalilov Sh. From a strong state to a strong society: experience, analysis, practice. - T., 2001. $160 \mathrm{~b}$.

3. Saidov A.Kh. Neighbourhood and selfgovernment bodies: liberalization and modernization // Democratization and human rights. - T., 2000. No. $1.11-17$ b.

4. Komilov K. Opinions and Considerations on the need to improve the Law on Civil SelfGovernment Bodies on the basis of the Constitution of the Republic of Uzbekistan T., 1997. 149-151 p.

5. Suvankulov M. Theoretical and legal issues of the activities of citizens' self-government bodies in the Republic of Uzbekistan: Jurisprudence. Candidate of Sci ... Dis. autoref. - T., 2002. -24 p.

6. Sultanov S. Methodical handbook for the study of the basics of self-government of the state representative bodies of the Republic of Uzbekistan and citizens. - $T$.: Chulpon, 1996. $34 \mathrm{p}$.

7. Tulyaganov A. Organization of activities of representative and self-government bodies of state authority. Textbook. - T .: TSI, 2002. $196 \mathrm{p}$.

8. Malikova G.R. Transfer of some functions and powers of local state authorities to civil self-governance bodies (legal, organizational issues).Ye. autoref. -T., 2004. $-24 p$. 
9. Ismailova G.S. Organizational and legal problems of the activities of citizens' selfgovernment bodies in the Republic of Uzbekistan. Candidate of Law ... diss. $-T$., 2005.-174 p.

10. Reimova Z.A. Legal status of citizens' selfgovernment bodies in the Republic of Karakalpakstan. Doctor of Law diss.T., 2004.-139 p.

11. Umarova G.B. History of formation and improvement of self-government bodies in Uzbekistan. History. Candidate ... diss. T., 2003. - $164 \mathrm{p}$.

12. Shamsudinov R.T, A. ISAKOV'S Papers on the History of Andizhan.

13. National Encyclopedia of Uzbekistan. Volume 8 - T: State Scientific Publishing House, 2004. -20 p.

14. Jalilov Sh. From a strong state to a strong society. T. Uzbekistan. 2001.13 pages.

15. The modern history of Uzbekistan. 1 book. $T$. 2000. 204 pages.

16. Jalilov Sh. From a strong state to a strong society. T. Uzbekistan. 2001. pp. 16-17.

17. Leonid Levitin. Uzbekistan is in the historical turning point. Criticism of President Islam Karimov's supporters. T .. "Uzbekistan" 2001. -184 pages

18. kun.uz/.../shavkat-mirziyoyev- Mahalla Institute- signed a decree

19. Shavkat Mirziyoev. We will build a free and prosperous, democratic Uzbekistan together. Speech at the joint session of the chambers of the Oliy Majlis, dedicated to the inauguration of the President of the Republic of Uzbekistan. - Tashkent: Uzbekistan, 2017. -P. 12 